\title{
BIAYA SATUAN PENDIDIKAN DASAR DAN KEBUTUHAN DANA UNTUK PENDIDIKAN DASAR GRATIS
}

\author{
Abbas Ghozali \\ FEB Universitas Islam Negeri Jakarta (e-mail: abbas.ghozali@gmail.com)
}

\begin{abstract}
Abstrak: Biaya Satuan Pendidikan Dasar dan Dana yang Dibutuhkan untuk Pendidikan Dasar Gratis. Penelitian ini bertujuan untuk memperkirakan dana yang diperlukan untuk melaksanakan pendidikan dasar gratis pada tahun 2009 dan membandingkannya dengan realisasi anggaran untuk pendidikan dasar. Metode yang digunakan meliputi proyeksi pendaftaran, identifikasi sumberdaya pendidikan yang diperlukan, ketersediaan dan keterbatasan, identifikasi biaya satuan masing-masing unsur dan perkiraan total dana yang diperlukan. Temuan penelitian menunjukkan bahwa pelaksanaan pendidikan dasar pada tahun 2009 membutuhkan dana sebesar Rp157,22 trilyun, termasuk anggaran untuk SD dan SMP. Pemerintah pusat dan daerah menyediakan anggaran hanya Rp132,24 trilyun sehingga ada kekurangan sebesar Rp25 trilyun.
\end{abstract}

Kata Kunci: biaya satuan, pendidikandasar gratis

\begin{abstract}
The Unit cost of Basic Education and the Funds Needed for Free Basic Education. This study was aimed to estimate the funds needed to implement free basic education in 2009 and compare it with the budget realization for basic education. The methods employed included projection of enrollment, required educational resource identification, the availability and shortage, identification of the unit cost of each component, and estimation of the total funds needed. The findings revealed that implementing free basic education in 2009 required as much as Rp157.22 trillion, including the budget for primary schools and junior secondary schools. The national and regional government levels provided the budget for basic education as much as Rp132.24 trillion only, and so there was a deficit of Rp25 trillion.
\end{abstract}

Keywords: unit cost, free basic education

\section{PENDAHULUAN}

Setiap warga negara Indonesia berhak mendapatpendidikan, bahkan warga negara yang berusia tujuh sampai dengan lima belas tahun wajib mengikuti pendidikan dasar dan setiap warga negara yang berusia 6 tahun dapat mengikuti program wajib belajar serta orang tua dari anak usia wajib belajar berkewajiban memberikan pendidikan dasar kepada anaknya. (UUD 1945 Pasal 31 Ayat 2, UU Sisdiknas Pasal 6 Ayat 1, Pasal 7, dan Pasal 34). Pemerintah Pusat dan Pemerintah Daerah 
wajib membiayainya serta Pemerintah Pusat dan Pemerintah Daerah menjamin terselenggaranya wajib belajar minimal pada jenjang pendidikan dasar tanpa memungut biaya. (UUD $1945 \mathrm{~Pa}-$ sal 31 Ayat 2, UU Sisdiknas Pasal 11 Ayat 2, Pasal 34 Ayat 2, dan Pasal 46 Ayat 1). Artinya, pendidikan dasar itu gratis bagi semua warga negara Indonesia.

Apa yang dimaksud dengan pendidikan gratis? Wikipedia menyebutkan pendidikan gratis sebagai pendidikan yang diberikan kepada siswa tanpa pungutan biaya. Akan tetapi, siswa mungkin tetap mempunyai pengeluaran untuk mendapatkan pendidikan gratis, seperti buku dan bahan ajar lain. Pendidikan gratis dapat pula diberikan kepada siswa dalam bentuk beasiswa atau hibah yang menutup semua atau hampir semua pengeluaran siswa untuk dapat mengikuti kegiatan sekolah (Wikipedia, 2008).

The United Nations Educational, Scientific, and Cultural Organization (UNES$\mathrm{CO})$ menyatakan bahwa salah satu tujuan Education for All (EFA) adalah sekolah mesti bebas dari pungutan. (UNESCO, 2008). Ini berarti bahwa orang tua tidak perlu membayar iuran sekolah agar anaknya belajar di sekolah. Selain itu, orangtua tidak perlu membayar berbagai pengeluaran lain yang membuat anak-anak miskin tidak bersekolah. Pengeluaran tersebut antara lain membeli buku teks, biaya partisipasi dalam kegiatan olahraga, dan lain-lain.

Bank Dunia dalam laporan pembangunan dunia Tahun 2006 menyatakan bahwa pengurangan iuran di se- kolah dasar telah terbukti meningkatkan pendaftaran (enrollment). Selain itu, laporan BankDunia tersebutjuga menggambarkan bahwa pengurangan biaya seperti iuran sekolah atau biaya input lainnya seperti buku dan seragam sekolah dapat meningkatkan partisipasi pendidikan (World Bank, 2006:137-138).

Meski gratis bagi peserta didik, penyelenggaraan pendidikan dasar membutuhkan dana dan pemerintahlah yang harus menyediakan dana tersebut. Penyelenggaraan pendidikan dasar dilakukan melalui satuan-satuan pendidikan sekolah dasar (SD), madrasah ibtidaiyah (MI), dan yang sederajat serta sekolah menengah pertama (SMP), madrasah tsanawiayh (MTs), dan yang sederajat. Untuk menyelenggarakan pendidikan dasar di satuan pendidikan dasar dibutuhkan sumber daya pendidikan dasar. Penggunaan sumber daya pendidikan berakibat pada biaya. Biaya pendidikan dasar tersebut harus ditanggung oleh pemerintah.

Sumber daya pendidikan meliputi pendidik dan tenaga kependidikan serta sarana dan prasarana pendidikan. (UU Sisdiknas Pasal 1 ayat 23). Pendidik adalah sumber daya manusia di sekolah/madrasah yang bergumul langsung dengan peserta didik dalam proses belajar-mengajar, seperti guru dan konselor; sedangkan, tenaga kependidikan adalah sumber daya manusia di sekolah/madrasah yang menunjang proses pendidikan peserta didik, seperti kepala sekolah/madrasah, pustakawan, laboran, teknisi, tata usaha, bendahara, juru ketik, penjaga/petugas kebersihan, dan lain-lain (UU Sisdiknas Pasal 1 ayat 5 dan 6). 
Penyediaan pendidik dan tenaga kependidikan berakibat pada biaya. Lembaga pendidikan harus memberikan dana pengganti atas keahlian, pikiran, dan waktu yang mereka curahkan dalam proses pendidikan. Ada dua bentuk dana pengganti yang diberikan kepada pendidik dan tenaga kependidikan, yaitu: a) yang berfungsi untuk menjamin kesejahteraan seperti gaji, tunjangan, dan lain-lain dan b) yang berungsi untuk mengembangkan mutu, seperti pendidikan, pelatihan, lokakarya, dan lain-lain. Kedua macam dana penggantiyang diberikan lembaga pendidikan tersebut menyangkut dua macam biaya, yaitu biaya operasional pendidik dan tenaga kependidikan dan biaya investasi pendidik dan tenaga kependidikan. Biaya operasional pendidik dan tenaga kependidikan adalah biaya yang timbul sebagai akibat pemberian dana pengganti kepada pendidik dan tenaga kependidikan yang sama dengan frekuensi satu kali atau lebih dalam satu tahun. Dana pengganti berupa gaji, tunjangan, dan lainlain merupakan biaya operasional pendidikan dan tenaga kependidikan. Biaya investasi pendidik dan tenaga kependidikan adalah biaya yang timbul sebagai akibat pemberian dana pengganti kepada pendidik dan tenaga kependidikan yang sama dengan frekuensi hanya satu kali untuk selamanya atau berulang tetapi untuk lebih dari satu tahun. Dana pengganti berupa penyediaan dana untuk pendidikan, pelatihan, lokakarya, seminar, dan lainlain bagi pendidik dan tenaga kependidikan merupakan biaya investasi pendidik dan tenaga kependidikan.
Prasarana pendidikan adalah fasilitas dasar untuk menjalankan fungsi sekolah/madrasah(PeraturanMenteriPendidikan Nasional tentang Standar Sarana dan Prasarana Pendidikan). Prasarana pendidikan meliputi lahan, ruang kelas, ruang pimpinan satuan pendidikan, ruang pendidik, ruang tata usaha, ruang perpustakaan, ruang laboratorium, ruang bengkel kerja, ruang unit produksi, ruang kantin, instalasi daya dan jasa, tempat berolahraga, tempat beribadah, tempat bermain, tempat berkreasi, dan ruang/tempat lain yang diperlukan untukmenunjang proses pembelajaran yang teratur dan berkelanjutan (Pasal 42 PP Standar Nasional Pendidikan). Prasarana pendidikan ini masa pakainya lebih dari satu tahun. Sarana pendidikan adalah perlengkapan pembelajaran yang dapat dipindah-pindah (Peraturan Menteri Pendidikan Nasional tentang Standar Sarana dan Prasarana Pendidikan). Ada dua macam sarana pendidikan, yaitu sarana pendidikan yang masa pakainya lebih dari satu tahun seperti perabot, peralatan, media pendidikan, buku dan sumber belajar lainnya, dan lain-lain dan sarana pendidikan yang masa pakainya kurang dari satu tahun seperti bahan dan alat pendidikan habis pakai.

Pengadaaan sarana dan prasarana pendidikan serta pemeliharaan dan perbaikan ringannya berakibat pada biaya pendidikan. Biaya pendidikan yang muncul sebagai akibat dari pengadaan sarana dan prasana pendidikan yang masa pakainya lebih dari satu tahun disebut biaya investasi sarana dan prasarana pendidikan; sedangkan, biaya pemeliharaan dan perbaikan 
ringannya disebut biaya operasional pemeliharaan dan perbaikan ringan karena biaya ini dikeluarkan satu tahun satu kali atau beberapa kali. Selain itu, biaya pendidikan yang muncul sebagai akibat dari pengadaan sarana pendidikan yang masa pakainya kurang atau sama dengan satu tahun disebut biaya operasional bahan dan alat habis pakai. Apabila biaya operasional bahan dan alat habis pakai digabung dengan biaya operasional pemeliharaan dan perbaikan ringan disebut biaya operasional bahan dan alat habis pakai serta pemeliharaan dan perbaikan ringan.

Dengan demikian, biaya pendidikan dapat dikelompokkan ke dalam empat kategori, yaitu: 1) biaya operasional pendidik dan tenaga kependidikan; 2) biaya investasi pendidik dan tenaga kependidikan; 3) biaya operasional bahan dan alat habis pakai serta pemeliharaan dan perbaikan ringan; dan 4) biaya investasi sarana dan prasarana pendidikan. Apabila masing-masing biaya pendidikan tersebut dibagi dengan jumlah peserta didik yang ada di sekolah/madrasah tersebut per tahun maka biayabiaya itu disebut: a) biaya satuan operasional pendidik dan tenaga kependidikan; b) biaya satuan investasi pendidik dan tenaga kependidikan; c) biaya satuan operasional bahan dan alat habis pakai serta pemeliharaan dan perbaikan ringan; dan d) biaya satuan investasi sarana dan prasarana pendidikan. Gabungan dari keempat biaya satuan ini disebut biaya satuan pendidikan yang berarti biaya pendidikan per peserta didik per tahun.

Perumusan masalah dalam studi ini adalah berapa biaya satuan pen- didikan dasar menurut masing-masing bagian biaya pendidikan dasar serta berapa biaya operasional pendidik dan tenaga kependidikan, biaya investasi pendidikdan tenaga kependidikan, biaya operasional bahan dan alat habis pakai serta pemeliharaan dan perbaikan ringan, dan biaya insvestasi sarana dan prasarana untuk pendidikan dasar di Indonesia pada tahun 2009. Dengan dihitungnya semua biaya tersebut dapat diperkirakan kebutuhan dana untuk penyelenggaraan pendidikan dasar gratis di Indonesia pada tahun 2009.

\section{METODE}

Studi ini dilakukan melalui beberapa kegiatan yang saling berkaitan, yang dapat dikelompokkan dalam enam tahap seperti terlihat dalam Gambar 1. Pada tahap pertama dicirikan bagian sumber daya pendidikan dasar. Pencirian bagian sumber daya pendidikan dasar dikerjakan dengan merujuk pada Peraturan Menteri Pendidikan Nasional Nomor 22 Tahun 2006 tentang Standar Isi, Peraturan Menteri Pendidikan Nasional Nomor 26 Tahun 2006 tentang Standar Pendidik dan Tenaga Kependidikan, Peraturan Menteri Pendidikan Nasional Nomor 25 Tahun 2006 tentang Standar Pengelolaan Pendidikan, dan Peraturan Menteri Pendidikan Nasional Nomor 24 Tahun 2007 tentang Standar Sarana dan Prasarana Pendidikan. Tujuan pencirian bagian sumber daya pendidikan dasar adalah untuk mengetahui sumber daya pendidikan dasar standar yang dibutuhkan untuk menyelenggarakan pendidikan dasar yang bermutu. 


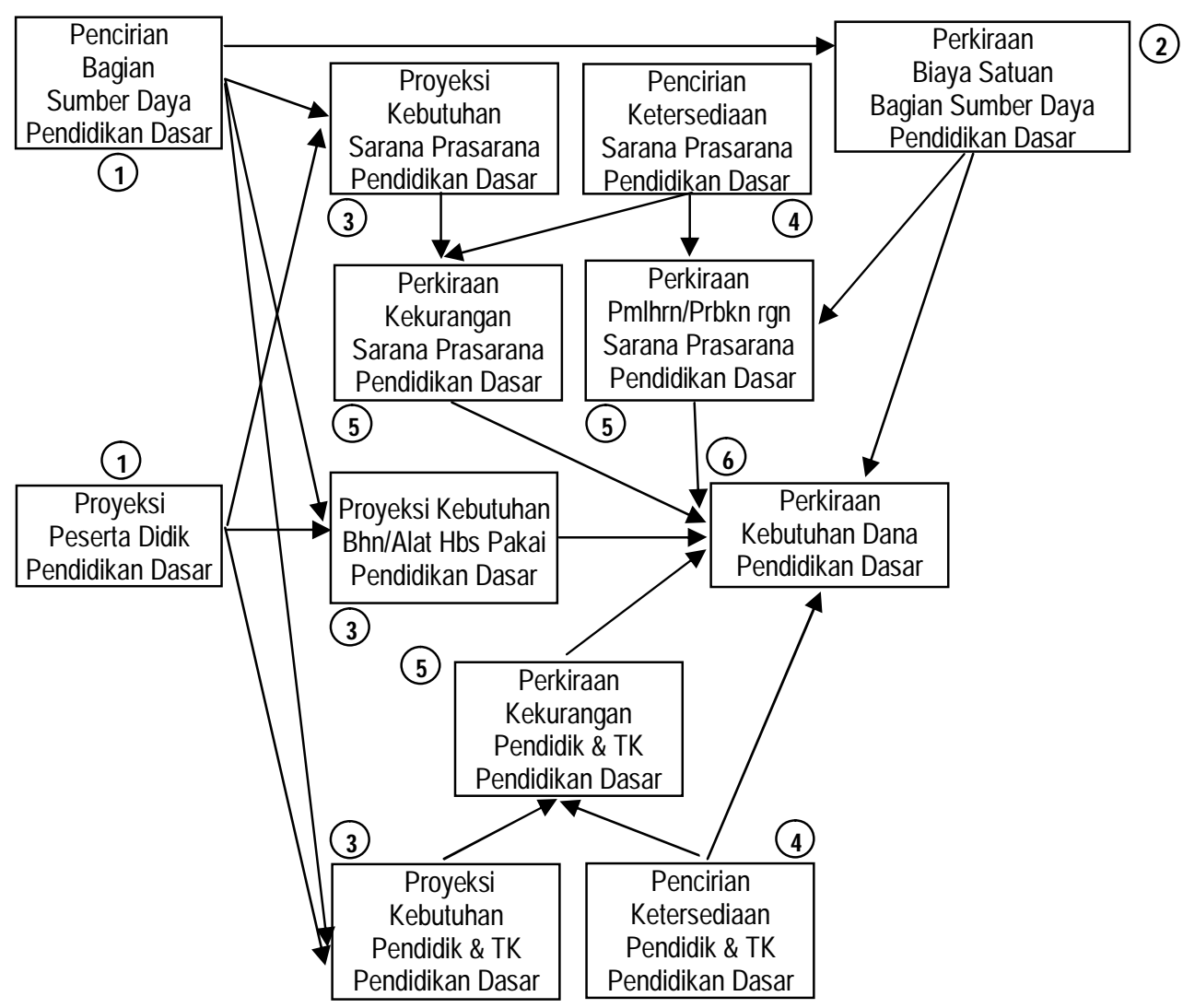

\section{Gambar 1 Bagan Studi Pendidikan Dasar Gratis}

Pada tahap pertama ini juga dilakukan proyeksi peserta didik pendidikan dasar tahun 2009 dengan menggunakan metode cohort. Data yang diperlukan meliputi proyeksi penduduk usia pendidikan dasar (7 s.d. 15 tahun) yang usia tunggal dan tahun tunggal (single age and single year) yang dihasilkan dengan memecah hasil proyeksi lima (5) tahunan Badan Pusat Statistik (BPS) yang menggunakan hasil sensus penduduk (SP) tahun 2000 serta pendaftaran peserta didik di masing-masing tingkat di SDMI dan SMPMTs tahun 2008, angka penyerapan SDMI dan SMPATs, angka naik (lulus), angka mengulang, dan angka putus sekolah/ madrasah di masing-masing tingkat di SDMI dan SMPMTs tahun 2009 yang diperoleh dari Pusat Statistik Pendidikan Kementerian Pendidikan Nasional.

Dengan sudah dicirikannya bagian sumber daya pendidikan dasar dapat diperkirakan biaya satuan bagian sumber daya pendidikan dasar. Perkiraan biaya satuan bagian sumber daya pendidikan dasar dilakukan pada tahap kedua dengan menggunakan berbagai sumber data tentang harga sumber daya pendidikan dasar seperti peraturan perundang-undangan, sekolah/madrasah, Kementerian Pekerjaan Umum, 
Kementerian Keuangan, dan penyedia bahan dan peralatan pendidikan pada tahun 2009.

Hasil proyeksi peserta didik pendidikan dasar bersama hasil pencirian bagian sumber daya pendidikan dasar digunakan untuk memproyeksikan kebutuhan sumber daya pendidikan dasar yang meliputi sarana prasarana, bahan dan alat habis pakai, serta pendidik dan tenaga kependidikan. Proyeksi kebutuhan berbagai sumber daya pendidikan dasar yang dilakukan pada tahap ketiga ini menggunankan rumusrumus hubungan antara peserta didik dengan sumber daya pendidikan yang terdapat dalam standar-standar pendidikan nasional, terutama standar isi, standar proses, standar pengelolaan, standar sarana dan prasarana, serta standar pendidik dan tenaga kependidikan untuk pendidikan dasar.

Pada tahap keempat dicirikan (diteliti) sumber daya pendidikan dasar yang tersedia pada tahun 2009, terutama sarana dan prasarana serta pendidik dan tenaga kependidikan. Pencirian sumber daya pendidikan dasar yang tersedia dilakukan dengan menganalisis statistik pendidik dan tenaga kependidikan serta sarana dan prasarana pendidikan dasar yang terdapat di Pusat Statistik Pendidikan Kementerian Pendidikan Nasional tahun 2009.

Dengan membandingkan proyeksi kebutuhan sumber daya pendidikan dasar dan hasil pencirian ketersediaan sumber daya pendidikan dasar dapat diperkirakan kekurangan sumber daya pendidikandasar pada tahun 2009 yang dilakukan pada tahap kelima. Perkiraan sumber daya pendidikan dasar yang kurang dan harus disediakan tersebut dapat dikelompokkan ke dalam sarana dan prasarana, bahan dan alat habis pakai, serta pendidik dan tenaga kependidikan. Pada tahap kelima ini juga dilakukan perkiraan pemeliharaan dan perbaikan ringan sarana dan prasarana pendidikan dasar dengan mengacu pada ketersediaan sarana dan prasarana pendidikan dasar.

Hasil perkiraan kebutuhan dan kekurangan sumber daya pendidikan dasar dan hasil perkiraan biaya satuan bagian sumber daya pendidikan dasar dapat digunakan untuk memerkirakan kebutuhan dana pendidikan dasar pada tahun 2009 yang dilakukan pada tahap keenam.

\section{HASIL}

Dalam bagian ini akan disampaikan hasil dan pembahasan tentang proyeksi peserta didik pendidikan dasar, biaya satuan pendidikan dasar, dan kebutuhan dana pendidikan dasar gratis.

\section{Proyeksi Peserta Didik Pendidikan Dasar}

Hasil proyeksi peserta didik SDMI dan SMPMTs untuk tahun ajaran 2009/ 210 seperti dapat dilihat dalam Tabel 1 adalah masing-masing 28.718 .963 anak dan 11.183.834 anak. 
Tabel 1. Proyeksi Peserta didik SD, MI, SMP, dan MTs Tahun Ajaran 2009/2010

\begin{tabular}{cccccc}
\hline \multicolumn{2}{c}{ Jumlah Peserta didik (Anak) } & \multicolumn{3}{c}{ Jumlah Peserta didik (Anak) } \\
\hline SD & MI & SD + MI & SMP & MTs & SMP + MTs \\
25.321 .244 & 3.397 .719 & 28.718 .963 & 8.915 .703 & 2.268 .131 & 11.183 .834 \\
\hline
\end{tabular}

\section{Biaya Satuan Pendidikan Dasar}

Seperti diuraikan pada Bagian 1, biaya satuan pendidikan dasar dapat dikelompokkan dalam: 1) biaya satuan operasional pendidik dan tenaga kependidikan; 2) biaya satuan operasional bahan dan alat habis pakai serta pemeliharaan dan perbaikan ringan; 3) biaya satuan investasi pendidik dan tenaga kependidikan; dan 4) biaya satuan investasi sarana dan prasarana pendidikan. Hasil perhitungan biaya satuan pendidikan dasar ini disajikan dalam Tabel 2.

Biaya satuan pendidikan per peserta didik per tahun pada tahun 2009 adalah sebesar Rp3,691 juta untuk jenjang SDMI dan Rp5,685 juta untuk jenjang SMPMTs. Biaya satuan pendidikan ini pada jenjang SDMI terdiri dari biaya satuan operasional pendidik dan tenaga kependidikan sebesar Rp2,120 juta, biaya satuan operasional bahan dan alat habis pakai serta pemeliharaan dan perbaikan ringan sebesar Rp643 ribu, biaya satuan investasi pendidik dan tenaga kependidikan sebesar Rp23 ribu, dan biaya satuan investasi sarana dan prasarana sebesar Rp928 ribu. Sedangkan, pada jenjang SMP MTs biaya satuan pendidikan ini terdiri dari biaya satuan operasional pendidik dan tenaga kependidikan sebesar Rp2,947 juta, biaya satuan operasional bahan dan alat habis pakai serta pemeliharaan dan perbaikan ringan sebesar Rp792 ribu, biaya satuan investasi pendidik dan tenaga kependidikan sebesar Rp39 ribu, dan biaya satuan investasi sarana dan prasarana sebesar Rp1,906 juta.

\section{Tabel 2. Perkiraan Biaya Satuan Pendidikan untuk SD/MI} dan SMP/MTs Tahun 2009

\begin{tabular}{|c|c|c|}
\hline \multirow{2}{*}{ Komponen } & \multicolumn{2}{|c|}{ Biaya Satuan (Rp Ribu) } \\
\hline & SDMI & SMP MTs \\
\hline \multicolumn{3}{|l|}{ 1. Biaya Satuan Operasional (BSO) } \\
\hline 1.1 BSO Pendidik dan Tenaga Kependidikan & 2.120 & 2.947 \\
\hline $\begin{array}{l}\text { 1.2 BSO Bahan dan Alat Habis serta Pemeliharaan dan } \\
\text { Perbaikan Ringan }\end{array}$ & 643 & 792 \\
\hline Sub Total Biaya Satuan Operasional & 2.763 & 3.740 \\
\hline \multicolumn{3}{|l|}{ 2. Biaya Satuan Investasi (BSI) } \\
\hline 2.1 BSI Pendidik dan Tenaga Kependidikan & 23 & 39 \\
\hline 2.2 BIS Sarana dan Prasarana & 928 & 1.906 \\
\hline Sub Total Biaya Satuan Investasi & 904 & 1.945 \\
\hline Total Biaya Satuan Pendidikan & 3.691 & 5.685 \\
\hline
\end{tabular}


Keterangan:

Sesuai dengan Standar Sarana dan Sarana Pendidikan, SDMI yang dimaksud memiliki 6 rombongan belajar dengan setiap rombongan belajar terdapat 28 peserta didik, yang berarti SDMI tersebut memiliki 168 Peserta didik; sedangkan, SMPAMTs yang dimaksud memiliki 6 rombongan belajar dengan setiap rombongan belajar terdapat 40 peserta didik, yang berarti SMP MTs tersebut memiliki 240 Peserta didik.

\section{Kebutuhan Dana Pendidikan Dasar Gratis}

Bagian ini akan memperkirakan kebutuhan sumber daya pendidikan dasar dan biayanya untuk tahun 2009 yang sekaligus juga berarti memperkirakan kebutuhan dana untuk penyelenggaraan pendidikan dasar gratis di seluruh Indonesia tahun 2009. Dengan menggunakan hasil proyeksi jumlah peserta didik pendidikan dasar tahun 2009 yang dibahas dalam Sub Bagian 3.1, hasil proyeksi kebutuhan sumber daya pendidikan dasar tahun 2009; hasil pencirian sumber daya pendidikan dasar yang tersedia pada tahun 2008 dan proyeksinya untuk tahun 2009, dan hasil perkiraan biaya satuan pendidikan dasar untuk tahun 2009 yang dibahas dalam Sub Bagian 3.2 maka dapat dihitung kebutuhan sum- ber daya pendidikan dasar baik dalam bentuk unit maupun biayanya dalam nilai rupiah untuk penyelenggaraan pendidikan dasar gratis tahun 2009.

Dalam sub-sub bagian berikut ini berturut-turut akan disampaikan hasil perkiraan kebutuhan sumber daya pendidikan dalam bentuk unit dan dana untuk menutup biaya operasional pendidik dan tenaga kependidikan, biaya operasional bahan dan alat habis pakai serta pemeliharaan dan perbaikan ringan, biaya investasi pendidik dan tenaga kependidikan, dan biaya investasi sarana dan prasarana, serta akhirnya biaya total pendidikan dasar yang mencakup SDMI dan SMPMTs di seluruh Indonesia untuk tahun 2009. Dengan demikian, dapat diperkirakan kebutuhan dana untuk penyelenggaraan pendidikan dasar gratis di Indonesia tahun 2009.

\section{Biaya O p e r a s i o n a 1 Pendidik dan Tenaga Kependidikan}

Perkiraan biaya operasional pendidik dan tenaga kependidikan untuk SDMI dan SMPMTs pada tahun 2009 disajikan dalam Tabel 3. Biaya operasional pendidik dan tenaga kependidikan ini merupakan biaya untuk memberikan gaji dan tunjangan kepada pendidik, kepala s e k o l a h /madrasah, pustakawan/tata usaha, dan tenaga keamanan/kebersihan. 


\section{Tabel 3. Perkiraan Biaya Operasional Pendidik dan Tenaga Kependidikan untuk SD/MI dan SMP/MTs pada Tahun 2009}

\begin{tabular}{|c|c|c|c|c|c|c|c|}
\hline \multirow[b]{2}{*}{$\begin{array}{c}\text { Kesejahteraan Pendidik } \\
\text { Dan Tenaga Kependidikan }\end{array}$} & \multirow[b]{2}{*}{ Satuan } & \multicolumn{3}{|c|}{ SDMI } & \multicolumn{3}{|c|}{ SMPMTs } \\
\hline & & Jumlah & $\begin{array}{c}\text { Nilai per } \\
\text { Satuan per } \\
\text { Tahun (Rp) }\end{array}$ & $\begin{array}{c}\text { Nilai Total } \\
\text { per Tahun } \\
\text { (Rp Juta) }\end{array}$ & Jumlah & $\begin{array}{l}\text { Nilai per } \\
\text { Satuan per } \\
\text { Tahun (Rp) }\end{array}$ & $\begin{array}{l}\text { Nilai Total } \\
\text { r per Tahun } \\
\text { (Rp Juta) }\end{array}$ \\
\hline \multicolumn{8}{|l|}{$\begin{array}{l}\text { 1. Pendidik PNS dan } \\
\text { Swasta }\end{array}$} \\
\hline 1.1 Gaji pokok pendidik & Org & 1.454 .806 & 17.054 .069 & 24.810 .361 & 693.515 & 18.174 .248 & 12.604 .114 \\
\hline 1.2 Tur & Org & 1.45 & 2.719 .595 & 3.956 & 693.515 & 2.719 .595 & 1.886 .080 \\
\hline $1.3 \mathrm{~T}$ & Org & 1.284 & 3.337.017 & 4.286 .632 & 693.515 & ; 3.337.017 & 2.314 .271 \\
\hline 1.4 Tun & Org & 290.961 & 17.054 .069 & 4.962 .072 & 208.055 & 18.174 .248 & 3.781 .234 \\
\hline $\begin{array}{l}1.5 \text { Tunj khusus di d } \\
\text { terpencil }\end{array}$ & Org & 13.800 & 18.547 .380 & 255.954 & 6.200 & 18.547 .380 & 114.994 \\
\hline $\begin{array}{l}\text { 1.6 Kelebihan jam } \\
\text { mengajar }\end{array}$ & JPL & 14.174 .659 & 2.290 & 32.457 & 7.016.196 & 2.290 & 16.066 \\
\hline $\begin{array}{l}\text { gaan akhir } \\
\text { ti }\end{array}$ & $\mathrm{O}$ & 31.050 & 1.717 .350 & 53.324 & 3.950 & 1.717 .350 & 23.957 \\
\hline $\begin{array}{l}\text { 2. Tunj } \\
\text { sekol }\end{array}$ & & & 6.277 .120 & 2 & 7 & 6.8 & 8 \\
\hline $\begin{array}{l}\text { 3. Gaji dan tunj tenaga } \\
\text { instalasi }\end{array}$ & Org & & & & 207 & 19.375 .280 & 798.397 \\
\hline $\begin{array}{l}\text { 4. Gaji dan tunj tenaga } \\
\text { laboratorium }\end{array}$ & Org & & & & 41.207 & 19.375 .280 & 798.397 \\
\hline $\begin{array}{l}\text { 5. Gaji dan tunj tenaga } \\
\text { perpustakaan }\end{array}$ & Org & & & & 41.207 & 19.375 .280 & 798.397 \\
\hline $\begin{array}{l}\text { 6. Gaji dan tunj tenaga tata } \\
\text { usaha }\end{array}$ & Org & 170.236 & 17.661 .200 & 3.006 .572 & 41.207 & 19.375 .280 & 798.397 \\
\hline $\begin{array}{l}\text { 7. Gaji dan tunj bendahara- } \\
\text { wan }\end{array}$ & Org & & & & 41.207 & 19.375 .280 & 798.397 \\
\hline 8. Gaji dan tunj juru ketik & $\mathrm{Or}$ & & & & & 17. & 702.626 \\
\hline $\begin{array}{l}\text { 9. Gaji dan tunj penjaga } \\
\text { sekolah }\end{array}$ & Org & 170.236 & 16.466 .048 & 2.803 .114 & 41.207 & 17.051 .129 & 702.626 \\
\hline TOTAL & & & & 45.235.562 & & & 26.421.451 \\
\hline
\end{tabular}

Keterangan:

- Jumlah pendidik SDMI PNS dan swasta dan pendidik SMPMTs PNS dan swasta masing-masing sebanyak 1,455 juta orang dan 694 ribu orang pada tahun 2009 diperoleh dari dokumen "Rencana Kerja Pembangunan Tahun 2009" yang disusun oleh Ditjen PMPTK Kementerian Pendidikan Nasional.

- Gaji pokok pendidik SDMI PNS dan swasta dengan rata-rata Golongan IIIB dan pengalaman mengajar enam tahun sebesar Rp17.054.069 dan gaji pokok pendidik SMP MTs PNS dan swasta dengan rata-rata Golongan IIIC dan pengalaman mengajar delapan tahun sebesar Rp18.174.248 per tahun pada tahun 2009 didasarkan pada Peraturan Pemerintah No. 66 Tahun 2006 tentang Daftar Gaji Pokok PNS dengan memperhitungkan inflasi tahun 2006, 2007, dan 2008 sebesarmasing-masing 7 persen.

- Tunjangan yang melekat bagi pendidik SDMI PNS dan swasta dengan 
rata-rata Golongan IIIB dan pengalaman mengajar enam tahun dan tunjangan yang melekat pendidik SMP MTs PNS dan swasta dengan rata-rata Golongan IIIC dan pengalaman mengajar delapan tahun sebesar Rp2.719.595 per tahun pada tahun 2009 didasarkan pada Peraturan Presiden No. 12 Tahun 2006 tentang Tunjangan Umum bagi PNS dengan memperhitungkan inflasi tahun 2006, 2007, dan 2008 sebesar masing-masing 7 persen.

- Tunjangan fungsional untuk pendidik SDMI dan SMPMTs PNS dan swasta sebesar Rp3.337.017 per tahun pada tahun 2009 dihitung berdasarkan Peraturan Presiden No. 58 Tahun 2006 tentang Tunjangan Tenaga Kependidikan yang disesuaikan dengan inflasi tahun-tahun 2006, 2007, dan 2008 masing-masing 7 persen.

- Jumlah pendidik SDMI PNS dan swasta pada tahun 2009 yang mendapat tunjangan profesi sebanyak 290.961 orang merupakan 20 persen dari total pendidik SDMI PNS dan swasta pada tahun 2009. Jumlah pendidik SMPATs PNS dan swasta pada tahun 2009 yang mendapat tunjangan profesi sebanyak 208.055 orang merupakan 30 persen dari total pendidik SMPMTs PNS dan swasta pada tahun 2009. Besarnya tunjangan profesi adalah satu kali gaji pokok yang didasarkan pada UU No. 14 Tahun 2005 tentang Guru dan Dosen Pasal 16 ayat 2.

- Jumlah pendidik SDMI dan SMP/ MTS pada tahun 2009 yang mendapat tunjangan khusus daerah terpen- cil masing-masing sebanyak 13.800 orang dan 6.200 orang dengan besarnya tunjangan Rp18.547.380 per orang bersumber dari "Rencana Kerja Pembangunan Tahun 2009" yang disusun oleh Ditjen PMPTK Kementerian Pendidikan Nasional dan diolah untuk pendidik SDMI.

- Jumlah kelebihan jam mengajar pendidik SDMI dan SMP MTs PNS dan swasta pada tahun 2009 sebanyak masing-masing 14,174 juta jam dan 7,016 juta jam dengan honor Rp2.290 per jam bersumber dari "Pagu Indikatif 2009" yang disusun oleh Ditjen PMPTK Kementerian Pendidikan Nasional yang disesuaikan dengan 7 persen inflasi tahun 2007 yang diolah untuk pendidik SDMI PNS.

- Jumlah pendidik SDMI PNS dan swasta dan pendidik SMPMTs PNS dan swasta yang menerima penghargaan masa bakti pada tahun 2009 sebanyak masing-masing 31.050 orang dan 13.950 orang dengan nilai $\mathrm{Rp}$ 1.717.350 bersumber dari "Pagu Indikatif 2009" yang disusun oleh Ditjen PMPTKKementerian Pendidikan Nasional.

- Jumlah kepala sekolah/madrasah, tenaga tata usaha dan penjaga sekolah SDMI PNS dan swasta dan jumlah kepala sekolah/madrasah, tenaga instalasi, tenaga perpustakaan, tenaga laboratorium, tenaga tata usaha, bendaharawan, juru ketik, dan penjaga sekolah SMPMTs pada tahun 2009 adalah hasil estimasi dengan menggunakan data tahun 2008, estimasi kebutuhan tenaga berdasarkan perkembangan jumlah sekolah/madrasah, estimasi yang pensiun dan ke- 
luar serta yang direkrut pada tahun 2009.

- Tunjangan kepala SDMI dan kepala SMP MTs dengan rata-rata Golongan IV pada tahun 2009 sebesar masing-masing Rp6,277jutadan Rp6,880 juta dihitung berdasarkan Peraturan Presiden No. 58 Tahun 2006 tentang Tunjangan Tenaga Kependidikan yang disesuaikan dengan inflasi tahun-tahun 2006, 2007, dan 2008 masing-masing 7 persen.

- Gaji dan tunjangan tenaga instalasi, tenaga perpustakaan, tenaga laboratorium, tenaga tata usaha, dan bendaharawan SMPMTs dengan ratarata Golongan IIIA dan masa kerja 8 tahun pada tahun 2009 sebesar Rp19,375 juta dihitung berdasarkan Peraturan Pemerintah No. 66 Tahun 2006 tentang Daftar Gaji Pokok PNS dan Peraturan Presiden No. 12 Tahun 2006 tentang Tunjangan Umum bagi PNS yang disesuaikan dengan inflasi tahun-tahun 2006, 2007, dan 2008 masing-masing 7 persen.

- Gaji dan tunjangan tenaga tata usaha SDMI dengan rata-rata Golongan IID dan masa kerja 7 tahun pada tahun 2009 Rp15,426 juta dihitung berdasarkan Peraturan Pemerintah No. 66 Tahun 2006 tentang Daftar Gaji Pokok PNS dan Peraturan Presiden No. 12 Tahun 2006 tentang Tunjangan Umum bagi PNS yang disesuaikan dengan inflasi tahun-tahun 2006, 2007, dan 2008 masingmasing 7 persen.

- Gaji dan tunjangan penjaga sekolah SDMI dengan rata-rata Golongan IIB dan masa kerja 7 tahun dan gaji dan tunjangan juru ketik dan pen- jaga sekolah dengan rata-rata Golongan IIC dan masa kerja 7 tahun pada tahun 2009 sebesar masing-masing Rp16,466 juta dan Rp17,051juta dihitung berdasarkan Peraturan Pemerintah No. 66 Tahun 2006 tentang Daftar Gaji Pokok PNS dan Peraturan Presiden No. 12 Tahun 2006 tentang Tunjangan Umum bagi PNS yang disesuaikan dengan inflasi tahun-tahun 2006, 2007, dan 2008 masing-masing 7 persen.

Untuk SD/MI pada tahun 2009 dengan jumlah peserta didik SDMI sebanyak 28.702 juta anak diperkirakan terdapat pendidik sebanyak 1.455 juta orang, kepala sekolah PNS sebanyak 170 ribu orang, tenaga tata usaha sebanyak 170 ribu orang, dan tenaga keamanan/kebersihan PNS sebanyak 170 ribu orang. Gaji dan tunjangan yang diberikan kepada pendidik dan tenaga kependidikan SDMI pada tahun 2009 berjumlah Rp 45,236 trilyun. Angka ini terdiri dari: Rp 38,357 trilyun untuk gaji pokok pendidik, tunjangan yang melekat pada gaji pendidik, tunjangan fungsional pendidik, tunjangan profesi pendidik, tunjangan khusus pendidik di daerah terpencil, kelebihan jam mengajar pendidik, dan penghargaan masa baktipendidik PNS; Rp1,069 trilyun untuk tunjangan kepala sekolah, Rp3,007 trilyun untuk gaji dan tunjangan tenaga tata usaha/perpustakaan PNS, dan Rp2,803 trilyun untuk gaji dan tunjangan penjaga sekolah/madrasah.

Untuk SMPAMTs pada tahun 2009 dengan jumlah peserta didik SMP MTs sebanyak 11 juta diperkirakan terdapat pendidik sebanyak 694 ribu orang serta kepala sekolah/madrasah, tenaga tek- 
nisi, tenaga laboratorium, tenaga perpustakaan, tenaga tata usaha, bendaharawan, juru ketik, dan penjaga sekolah/madrasah masing-masing sebanyak 41.207 ribu orang. Gaji dan tunjangan yang diberikan kepada pendidik dan tenaga kependidikan SMP/ MTs pada tahun 2009 berjumlah Rp26,421 trilyun. Angka ini terdiri dari: Rp20,741 trilyun untuk gaji pokok pendidik, tunjangan yang melekat pada gaji pendidik, tunjangan fungsional pendidik, tunjangan profesi pendidik, tunjangan khusus pendidik di daerah terpencil, kelebihan jam mengajar pendidik, dan penghargaan masa bakti pendidik; Rp283,498 milyar untuk tunjangan kepala sekolah/madrasah; Rp798,397 milyar untuk gaji dan tunjangan tenaga instalasi; Rp798,397 milyar untuk gaji dan tunjangan tenaga laboratorium; Rp798,397 milyar untuk gaji dan tunjangan tenaga perpustakaan; Rp798,397 milyar untuk gaji dan tunjangan tenaga tata usaha; Rp798,397 milyar untuk gaji dan tunjangan b e $\mathrm{n} \mathrm{d} \mathrm{a} \mathrm{h} \mathrm{a} \mathrm{r} \mathrm{a} \mathrm{w} \mathrm{a} \mathrm{n;}$ Rp702,626 milyar untuk gaji dan tunjangan juru ketik; dan Rp702,626 milyar untuk gaji dan tunjangan penjaga sekolah/madrasah.

Biaya Operasional Bahan dan Alat Habis Pakai dan Pemeliharaan

Perkiraan biaya operasional bahan dan alat habis pakai dan pemeliharaan untuk SDMI dan SMPMTs pada tahun 2009 disajikan dalam Tabel 4. Biaya operasional bahan dan alat habis pakai dan pemeliharaan adalah biayabiaya yang dikeluarkan untuk mengadakan bahan dan alat pendidikan yang habis digunakan dalam satu tahun atau kurang serta kegiatan dan pemeliharaan yang dilakukan satu tahun satu kali atau kurang. Biaya ini meliputi biaya-biaya untuk mengadakan alat tulis sekolah, bahan habis pakai, alat habis pakai, daya dan jasa, pemeliharaan sarana dan prasarana, pembinaan peserta didik, penilaian (penggandaan soal), rapat-rapat pendidik sekolah, dan perjalanan dinas.

Untuk SDMI pada tahun 2009 dengan jumlah peserta didik sebanyak 28.702 juta anak dan biaya operasional bahan dan alat habis pakai dan pemeliharaan sebesar Rp545 ribu per peserta didik per tahun, besarnya biaya operasional bahan dan alat habis pakai dan pemeliharaan untuk semua peserta didik adalah Rp15,649 trilyun. Untuk SMPATs pada tahun 2009 dengan jumlah peserta didik sebanyak 11.060 juta dan biaya operasional bahan dan alat habis pakai dan pemeliharaan sebesar Rp760 ribu per peserta didik per tahun, besarnya biaya operasional bahan dan alat habis pakai dan pemeliharaan untuk semua peserta didik adalah Rp8,401 trilyun. 
Tabel 4. Perkiraan Biaya Operasional Bahan dan Alat Habis Pakai serta Pemeliharaan dan Perbaikan Ringan SD/MI dan SMP/MTs pada Tahun 2009

\begin{tabular}{|c|c|c|c|c|c|c|}
\hline \multirow[b]{2}{*}{$\begin{array}{c}\text { Peserta didik dan } \\
\text { Bahan \& Alat Habis } \\
\text { Pakai serta } \\
\text { Pemeliharaan dan } \\
\text { Perbaikan Ringan }\end{array}$} & \multicolumn{3}{|c|}{ SDMI } & \multicolumn{3}{|c|}{ SMPMTs } \\
\hline & $\begin{array}{l}\text { Jumlah } \\
\text { (Orang) }\end{array}$ & $\begin{array}{c}\text { Biaya per } \\
\text { Peserta } \\
\text { didik }(R p)\end{array}$ & $\begin{array}{l}\text { Biaya } \\
\text { Total (Rp } \\
\text { Juta) }\end{array}$ & $\begin{array}{l}\text { Jumlah } \\
\text { (Orang) }\end{array}$ & $\begin{array}{c}\text { Biaya per } \\
\text { Peserta } \\
\text { didik } \\
(\mathrm{Rp}) \\
\end{array}$ & $\begin{array}{c}\text { Biaya } \\
\text { Total } \\
\text { (Rp Juta) }\end{array}$ \\
\hline Peserta didik & 28.702 .394 & & & 11.060 .344 & & \\
\hline $\begin{array}{l}\text { 1. Alat Tulis Sekolah } \\
\text { 2. Bahan dan Alat }\end{array}$ & & 102.292 & 2.936 .034 & & 117.369 & 1.298 .141 \\
\hline $\begin{array}{l}\text { Habis Pakai } \\
\text { 3. Daya dan Jasa }\end{array}$ & & $\begin{array}{l}50.974 \\
57.752\end{array}$ & $\begin{array}{l}1.463 .077 \\
1.657 .626\end{array}$ & & $\begin{array}{l}90.547 \\
77.714\end{array}$ & $\begin{array}{r}1.001 .477 \\
859.547\end{array}$ \\
\hline $\begin{array}{l}\text { 5. Pemeliharaan sarana } \\
\text { \& prasarana }\end{array}$ & & 135.770 & 3.896 .932 & & 192.881 & 2.133 .325 \\
\hline $\begin{array}{l}\text { 6. Pembinaan Peserta } \\
\text { didik }\end{array}$ & & 121.192 & 3.478 .509 & & 164.937 & 1.824 .264 \\
\hline $\begin{array}{l}\text { 7. Penilaian } \\
\text { (Penggandaan Soal) }\end{array}$ & & 36.751 & 1.054 .850 & & 51.682 & 571.622 \\
\hline $\begin{array}{l}\text { 8. Rapat-rapat } \\
\text { Penpendidiks Sekolah }\end{array}$ & & 9.114 & 261.603 & & 15.951 & 176.427 \\
\hline $\begin{array}{l}\text { 8. Kegiatan Komite } \\
\text { Sekolah }\end{array}$ & & 5.105 & 146.519 & & 2.552 & 28.223 \\
\hline $\begin{array}{l}\text { 9. Transport/Perjalanan } \\
\text { Dinas }\end{array}$ & & 26.251 & 753.479 & & 45.939 & 508.102 \\
\hline Total & & 545.203 & 15.648 .630 & & 759.572 & 8.401.127 \\
\hline
\end{tabular}

Biaya Investasi Pendidik dan Tenaga Kependidikan

Biaya investasi pendidik dan tenaga kependidikan adalah biaya-biaya yang dikeluarkan untuk meningkatkan mutu pendidik dan tenaga kependidikan. Biaya ini meliputi biaya-biaya untuk penerimaan tenaga baru, pendidikan, pelatihan, dan sertifikasi pendidik dan tenaga kependidikan. Perkiraan biaya investasi pendidik dan tenaga kependidikan untuk SD/MI dan SMP/ MTs pada tahun 2009 disajikan dalam Tabel 5.

Untuk SDMI pada tahun 2009 perlu dikeluarkan dana sebesar Rp1,588 trilyun untuk penerimaan tenaga baru, pendidikan D4/S1, pendidikan profesi, pelatihan, dan sertifikasi pendidik; sebesar Rp26,312 milyar untuk penerimaan tenaga baru dan pelatihan kepala sekolah/madrasah; Rp23,703 milyar untuk penerimaan tenaga baru tenga tata usaha; dan Rp5,282 milyar untuk penerimaan tenaga baru penjaga sekolah/ madrasah, sehingga seluruhnya berjumlah Rp1,643 trilyun. Untuk SMP/ MTs pada tahun 2009 perlu dikeluarkan dana sebesar Rp853,263 milyar untuk penerimaan tenaga baru, pendidikan $\mathrm{D} 4 / 51$, pendidikan profesi, pelatihan, dan sertifikasi pendidik; sebesar 
Rp6,493 milyar untuk penerimaan tenaga baru dan pelatihan kepala sekolah/madrasah; sebesar Rp5,656 milyar untuk penerimaan tenaga baru tenaga instalasi; sebesar Rp5,791 milyar untuk penerimaan tenaga baru tenaga laboran; sebesar Rp4,518 milyar untuk penerimaan tenaga baru tenaga perpustakaan; sebesar Rp46.007 milyar untuk penerimaan tenaga baru dan pelatihan tenaga tata usaha; sebesar Rp7,328 milyar untuk penerimaan tenaga baru dan pelatihan bendaharawan; sebesar Rp448 juta untuk penerimaan tenaga baru juru ketik; dan sebesar Rp1,469 milyar untuk penerimaan tenaga baru penjaga sekolah/madrasah; sehingga semuanya berjumlah Rp930,970 milyar.

\section{Biaya Investasi Sarana dan Prasarana}

Biaya investasi sarana dan prasarana adalah biaya-biaya yang dikeluarkan untuk membangun/mengadakan sarana dan prasarana pendidikan yang masa pakainya lebih dari satu tahun. Biaya ini meliputi biaya-biaya untuk membangunan/mengadakan lahan, bangunan, jaringan daya an jasa, perabot, peralatan, dan media pendidikan.

Perkiraan biaya investasi sarana dan prasarana untuk SDMI dan SMP/ MTs pada tahun 2009 disajikan dalam Tabel 6a dan Tabel 6b. Untuk SDMI pada tahun 2009 keperluan dana itu mencapai Rp 24,932 trilyun dan untuk
SMPAMTs pada tahun 2009 keperluan dana itu mencapai Rp34,008 trilyun.

\section{Biaya Total}

Dengan menjumlah biaya operasional pendidik dan tenaga kependidikan, biaya operasional bahan dan alat habis pakai serta pemeliharaan dan perbaikan ringan, biaya investasi pendidik dan tenaga kependidikan, dan biaya investasi sarana dan prasarana untuk pendidikan dasar, dapat diketahui biaya total pendidikan dasar. Pada Tabel 7 disajikan perkiraan biaya total pendidikan dasar pada tahun 2009 untuk SDMI dan SMPMTs yang sekaligus juga merupakan kebutuhan dana untuk menyelenggarakan pendidikan dasar gratis tahun 2009. Pada tahun 2009, diperkirakan kebutuhan dana untuk menyelenggarakan pendidikan dasar gratis mencapai Rp157,221 trilyun yang terdiri dari Rp87,460 trilyun untuk penyelenggaraan SD/MI dan Rp69,762 trilyun untuk penyeleggaraan SMP/ MTs. Dana penyelenggaraan SDMI sebesar Rp87,460 trilyun tersebut meliputi dana untuk menutupi biaya operasional sebesar Rp 60,884 trilyun dan dana untuk menutupi biaya investasi sebesar Rp26,576 trilyun. Dana penyelenggaraan SMPMTs sebesar Rp 69,762 trilyun tersebut meliputi dana untuk menutupi biaya operasional sebesar Rp34,822 trilyun dan dana untuk menutupi biaya investasi sebesar Rp34,939 trilyun. 


\section{Tabel 5. Perkiraan Biaya Investasi Pendidik dan Tenaga Kependidikan untuk SD/MI dan SMP/MTs pada Tahun 2009}

\begin{tabular}{|c|c|c|c|c|c|c|c|}
\hline \multirow[b]{2}{*}{$\begin{array}{l}\text { Pengembangan Pendidik dan } \\
\text { Tenaga Kependidikan }\end{array}$} & \multirow[b]{2}{*}{$\begin{array}{l}\text { Satu- } \\
\text { an }\end{array}$} & \multicolumn{3}{|c|}{ SDMI } & \multicolumn{3}{|c|}{ SMPMTs } \\
\hline & & Jumlah & $\begin{array}{l}\text { Biaya per } \\
\text { Orang (Rp) }\end{array}$ & $\begin{array}{c}\text { Biaya } \\
\text { Total (Rp } \\
\text { Juta) }\end{array}$ & Jumlah & $\begin{array}{l}\text { Biaya per } \\
\text { Orang (Rp) }\end{array}$ & $\begin{array}{c}\text { Biaya } \\
\text { Total } \\
\text { (Rp } \\
\text { Juta) }\end{array}$ \\
\hline \multicolumn{8}{|l|}{ 1. Pendidik } \\
\hline a. Penerimaan Tenaga Baru & Org & 58.192 & 286.225 & 16.656 & 107.261 & 286.225 & 30.701 \\
\hline b. Pendidikan D4/S1 & Org & 72.740 & 11.449 .000 & 832.804 & 38.076 & 11.449 .000 & 435.929 \\
\hline c. Pendidikan Profesi & Org & 36.370 & 11.449 .000 & 416.402 & 19.038 & 11.449 .000 & 217.965 \\
\hline d. Pelatihan & Org & 145.481 & 1.144 .900 & 166.561 & 76.152 & 1.144 .900 & 87.186 \\
\hline e. Sertifikasi & Org & 72.740 & 2.140 .000 & 155.664 & 38.076 & 2.140 .000 & 81.482 \\
\hline Sub Total & & & & 1.588.087 & & & 853.263 \\
\hline \multicolumn{8}{|l|}{ 2. Kepala Sekolah/Madrasah } \\
\hline a. Penerimaan Tenaga Baru & Org & 17.024 & 171.735 & 2.924 & 4.841 & 171.735 & 831 \\
\hline b. Pelatihan & Org & 17.024 & 1.373 .880 & 23.388 & 4.121 & 1.373 .880 & 5.661 \\
\hline Sub Total & & & & 26.312 & & & 6.493 \\
\hline \multicolumn{8}{|l|}{ 3. Tenaga Instalasi } \\
\hline a. Penerimaan Tenaga Baru & Org & & & & 19.759 & 286.225 & 5.656 \\
\hline \multicolumn{8}{|l|}{ 4. Tenaga Laboran } \\
\hline a. Penerimaan Tenaga Baru & Org & & & & 20.232 & 286.225 & 5.791 \\
\hline \multicolumn{8}{|l|}{ 5. Tenaga Pustaka } \\
\hline a. Penerimaan Tenaga Baru & Org & & & & 15.784 & 286.225 & 4.518 \\
\hline \multicolumn{8}{|l|}{ 6. Tenaga Tata Usaha } \\
\hline a. Penerimaan Tenaga Baru & Org & 82.812 & 286.225 & 23.703 & 12.390 & 286.225 & 3.546 \\
\hline b. Pelatihan & Org & & & & 41.207 & 1.030 .410 & 42.460 \\
\hline Sub Total & & & & & & & 46.007 \\
\hline \multicolumn{8}{|l|}{ 7. Bendaharawan } \\
\hline a. Penerimaan Tenaga Baru & Org & & & & 10.766 & 286.225 & 3.082 \\
\hline b. Pelatihan & Org & & & & 4.121 & 1.030 .410 & 4.246 \\
\hline Sub Total & & & & & & & 7.328 \\
\hline \multicolumn{8}{|l|}{ 8. Juru Ketik } \\
\hline a. Penerimaan Tenaga Baru & Org & & & & 1.954 & 228.980 & 448 \\
\hline \multicolumn{8}{|l|}{ 9. Penjaga/Kebersihan } \\
\hline a. Penerimaan Tenaga Baru & Org & 23.068 & 228.980 & 5.282 & 6.415 & 228.980 & 1.469 \\
\hline Total & & & & 1.643 .384 & & & 930.970 \\
\hline
\end{tabular}




\section{Keterangan:}

- Jumlah pendidik baru SDMI dan SMP MTs yang diterima pada tahun 2009 sama dengan proyeksi jumlah pendidik yang pensiun dan keluar yang diperkirakan sebesar empat persen dari jumlah pendidik yang ada pada tahun 2008 ditambah kebutuhan tambahan pendidik karena bertambahnya jumlah sekolah/madrasah.

- Jumlah pendidik SDMI dan SMP/ MTs yang diberi beasiswa pendidikan D4/S1 pada tahun 2009 masingmasing adalah lima persen dan dua setengah persen dari proyeksi jumlah pendidik SDMI dan SMPMTs yang ada pada tahun 2009.

- Jumlah pendidik SDMI dan SMP/ MTs yang diberi beasiswa pendidikan profesi pada tahun 2009 adalah masing-masing dua setengah persen dan satu seperempat persen dari proyeksi jumlah pendidik masingmasing SDMI dan SMPMTs yang ada pada tahun 2009.

- Jumlah pendidik SDMI dan SMP/ MTs yang mendapatkan pelatihan pada tahun 2009 adalah sepuluh persen dari proyeksi jumlah pendidik masing-masing SDMI dan SMP/ MTs yang ada pada tahun 2009.

- Jumlah pendidik yang memperoleh sertifikat sebagai pendidik profesional pada tahun 2008 dan 2009 merupakan lima persen dari proyeksi jumlah pendidik yang ada pada tahun-tahun 2008 dan 2009.

- Jumlah pendidik SDMI dan SMP/ MTs yang memperoleh sertifikat sebagai pendidik profesional pada ta- hun 2009 merupakan lima persen dari proyeksi jumlah pendidik SD/ MI dan SMP MTs yang ada pada tahun 2009.

- Jumlah kepala SDMI dan SMPMTs baru yang terima pada tahun 2009 sama dengan proyeksi jumlah kepala sekolah SDAMI dan SMPMTs yang pensiun dan keluar yang diperkirakan sebesar lima persen dari jumlah kepala sekolah SD/MI dan SMPAM yang ada pada tahun 2008 ditambah dengan kebutuhan tambahan kepala sekolah SDMI dan SMPMTs baru karena adanya penambahan SD/MIdan SMP MTs pada tahun 2009.

- Jumlah kepala SDMI dan SMP/MTs yang mendapatkan pelatihan pada tahun 2009 merupakan sepuluh persen dari proyeksi jumlah kepala SD/ MI dan SMPMTs yang ada pada tahun 2009.

- Jumlah tenaga tata usaha dan penjaga SDMI baru yang diterima pada tahun 2009 sama dengan proyeksi jumlah tenaga tata usaha dan penjaga yang dibutuhkan pada tahun 2009 dikurangi dengan jumlah tenaga tata usaha dan penjaga yang tersedia pada tahun 2008 setelah dikurangi dengan yang pensiun dan keluar pada tahun 2009 yang diperkirakan masing-masing tiga persen dan dua setengah persen dari jumlah tenaga tata usaha dan penjaga yang ada pada tahun 2008.

- Jumlah tenaga instalasi, laboran, pustakawan, tata usaha, bendaharawan, juru ketik dan penjaga sekolah SMPMTs baru yang diterima pada 
tahun 2009 sama dengan proyeksi jumlah yang dibutuhkan pada tahun 2009 dikurangi dengan jumlah yang tersedia pada tahun 2008 setelah di- kurangi yang pensiun dan keluar pada tahun 2009 yang diperkirakan besarnya sekitar tiga persen dari jumlah yang ada pada tahun 2008 .

\section{Tabel 6a. Perkiraan Biaya Investasi Sarana dan Prasarana untuk SD/MI dan SMP/MTs pada Tahun 2009}

\begin{tabular}{|c|c|c|c|c|c|c|c|}
\hline \multirow[b]{2}{*}{$\begin{array}{l}\text { Sarana dan Prasarana } \\
\text { Pendidikan }\end{array}$} & \multirow[b]{2}{*}{ Satuan } & \multicolumn{3}{|c|}{ SD/MI } & \multicolumn{3}{|c|}{ SMPMTs } \\
\hline & & Jumlah & $\begin{array}{l}\text { Harga per } \\
\text { Satuan (Rp) }\end{array}$ & $\begin{array}{l}\text { Harga } \\
\text { Total (Rp } \\
\text { Juta) }\end{array}$ & Jumlah & $\begin{array}{l}\text { Harga per } \\
\text { Satuan (Rp) }\end{array}$ & $\begin{array}{c}\text { Harga } \\
\text { Total (Rp } \\
\text { Juta) } \\
\end{array}$ \\
\hline Unit Sekolah Baru (USB) & unit & & & & 800 & 2.884.975.944 & 2.307.981 \\
\hline Ruang Kelas Baru (RKB) & unit & 100.000 & 103.480 .642 & 10.348 .064 & 13.120 & 118.263 .590 & 1.551 .618 \\
\hline Perabot Kelas & paket & 262.423 & 15.979 .369 & 4.193.361 & 51.212 & 24.152 .810 & 1.236 .915 \\
\hline Peralatan Kelas & paket & 368.552 & 688.657 & 253.806 & 83.127 & 1.420 .821 & 118.109 \\
\hline Ruang Perpustakaan & unit & & & & 10.379 & 194.026.203 & 2.013 .828 \\
\hline Perabot Perpustakaan & paket & 33.958 & 4.610 .512 & 156.564 & 13.796 & 22.800 .111 & 314.541 \\
\hline Peralatan Perpustakaan & paket & 56.773 & 927.369 & 52.649 & 16.529 & 9.178 .091 & 151.708 \\
\hline Media Belajar & paket & 33.958 & 54.529 .755 & 1.851 .721 & 14.420 & 122.701.727 & 1.769 .415 \\
\hline Ruang Lab IPA & unit & & & & 12.435 & 221.744.232 & 2.757.281 \\
\hline Perabot Laboratorium IPA & paket & & & & 14.258 & 56.753 .380 & 809.181 \\
\hline Peralatan Laboratorium IPA & paket & 56.773 & 5.686 .489 & 322.839 & 16.745 & 41.344 .171 & 692.290 \\
\hline Ruang Lab Komputer & unit & & & & 16.390 & 177.395.386 & 2.907 .509 \\
\hline Perabot Lab Komputer & paket & & & & 18.725 & 27.095 .203 & 507.360 \\
\hline Peralatan Lab Komputer & paket & & & & 16.578 & 128.830 .445 & 2.135 .791 \\
\hline Ruang Lab Bahasa & unit & & & & 18.642 & 221.744.232 & 4.133 .671 \\
\hline Perabot Lab Bahasa & paket & & & & 17.924 & 55.617 .296 & 996.901 \\
\hline Peralatan Lab Bahasa & paket & & & & 17.998 & 41.309 .824 & 743.505 \\
\hline Ruang Serba Guna & unit & 8.291 & 103.480 .642 & 857.978 & 16.669 & 221.744 .232 & 3.696 .340 \\
\hline Perabot di R. Serba Guna & paket & & & & 17.450 & 57.706 .166 & 1.006 .974 \\
\hline Peralatan di R. Serba Guna & paket & 56.773 & 6.985 .607 & 396.593 & 17.800 & 6.434 .567 & 114.537 \\
\hline Perabot Kesenian \& Ketrp. & paket & & & & 15.721 & 44.820 .545 & 704.602 \\
\hline Peralatan Keseninan & paket & 85.292 & 2.361 .356 & 201.404 & 16.283 & 17.516.169 & 285.209 \\
\hline Peralatan Keterampilan & paket & & & & 19.960 & 6.601 .493 & 131.766 \\
\hline Ruang Kantor & unit & 8.291 & 103.480 .642 & 857.978 & 2.580 & 171.851 .780 & 443.413 \\
\hline Perabot Kantor & paket & 33.958 & 43.724 .189 & 1.484 .785 & 7.994 & 48.002 .795 & 383.736 \\
\hline Peralatan Kantor & paket & 42.514 & 36.581 .845 & 1.555 .225 & 9.799 & 29.002 .034 & 284.181 \\
\hline Ruang Bimb \& Konseling & unit & & & & 2.580 & 16.630 .817 & 42.911 \\
\hline Perabot Konseling & paket & & & & 7.994 & 8.452 .797 & 67.572 \\
\hline Peralatan Konseling & paket & & & & 12.806 & 1.049 .873 & 13.445 \\
\hline Ruang UKS & unit & & & & 14.606 & 22.174 .423 & 323.874 \\
\hline Perabot UKS & paket & 28.254 & 5.605 .774 & 158.387 & 15.510 & 11.055 .154 & 171.470 \\
\hline Peralatan UKS & paket & 85.292 & 1.471 .998 & 125.549 & 9.799 & 1.629.193 & 15.964 \\
\hline Ruang PMR/Pramuka & uni & & & & 2.580 & 44.348 .846 & 114.429 \\
\hline Perabot PMR/Pramuka & paket & & & & 7.994 & 2.611 .288 & 20.875 \\
\hline
\end{tabular}




\section{Tabel 6b. Perkiraan Biaya Investasi Sarana dan Prasarana untuk SD/MI dan SMP/MTs pada Tahun 2009 (Lanjutan)}

\begin{tabular}{|c|c|c|c|c|c|c|c|}
\hline \multirow[b]{2}{*}{$\begin{array}{l}\text { Sarana dan Prasarana } \\
\text { Pendidikan }\end{array}$} & \multirow[b]{2}{*}{ Satuan } & \multicolumn{3}{|c|}{ SD/MI } & \multicolumn{3}{|c|}{ SMPMTs } \\
\hline & & Jumlah & $\begin{array}{l}\text { Harga per } \\
\text { Satuan (Rp) }\end{array}$ & $\begin{array}{c}\text { Harga } \\
\text { Total (Rp } \\
\text { Juta) }\end{array}$ & Jumlah & $\begin{array}{l}\text { Harga per } \\
\text { Satuan (Rp) }\end{array}$ & $\begin{array}{c}\text { Harga } \\
\text { Total (Rp } \\
\text { Juta) }\end{array}$ \\
\hline Peralatan PMR/Pramuka & paket & 85.292 & 1.230 .768 & 104.974 & 12.806 & 1.723 .075 & 22.066 \\
\hline Ruang Ibadah & unit & & & & 2.580 & 22.174 .423 & 57.215 \\
\hline Perabot Ibadah & paket & 33.958 & 2.023 .038 & 68.698 & 7.994 & 5.216 .164 & 41.698 \\
\hline Peralatan Ibadah & paket & 85.292 & 198.068 & 16.894 & 12.806 & 723.348 & 9.263 \\
\hline Ruang Partry & unit & 8.291 & 16.630 .817 & 137.889 & 2.580 & 16.630 .817 & 42.911 \\
\hline Perabot \& Peralatan Pantry & paket & 56.773 & 865.773 & 49.152 & 9.799 & 4.139 .042 & 40.557 \\
\hline Ruang WC \& KM & unit & 8.291 & 27.718 .029 & 229.815 & 2.580 & 66.523 .270 & 171.644 \\
\hline Perabot \& Per. WC \& KM & paket & 56.773 & 3.668 .260 & 208.258 & 18.822 & 6.766 .359 & 127.354 \\
\hline Gudang & unit & 8.291 & 33.261 .635 & 275.779 & 2.580 & 38.805 .241 & 100.125 \\
\hline Peralatan Olah Raga & paket & 42.514 & 12.689 .041 & 539.457 & 18.822 & 11.876 .735 & 223.540 \\
\hline Rumah Penjaga Sekolah & unit & 8.291 & 38.805 .241 & 321.742 & 2.580 & 38.805 .241 & 100.125 \\
\hline Perabot Rumah Penjaga & paket & 24.180 & 1.831 .840 & 44.294 & 6.791 & 10.739 .162 & 72.929 \\
\hline Peralatan Penjaga Sekolah & paket & 85.292 & 40.072 & 3.418 & 18.822 & 68.694 & 1.293 \\
\hline Jaringan Daya dan Jasa & unit & 15.291 & 7.510 .544 & 114.845 & 3.783 & 7.510 .544 & 28.414 \\
\hline Total & & & & 24.932.118 & & & 34.008 .036 \\
\hline
\end{tabular}

\section{Keterangan:}

- Pencirian jenis dan spesifikasi bagian sarana dan prasarana dilakukan dengan merujuk pada Peraturan Menteri Pendidikan Nasional Nomor 27 Tahun 2006 tentang Standar Sarana dan Prasarana Pendidikan.

- Jumlah sarana dan prasarana yang harus diadakan pada tahun 2009 diperkirakan dengan memproyeksikan kebutuhan sarana dan pasarana sesuai dengan proyeksi perkembangan jumlah peserta didik pada tahun 2009 dikurangi dengan jumlah sarana dan prasarana yang tersedia pada tahun 2008 setelah memperhitungkan penyusutan pada tahun 2008.

- Harga satuan ditentukan berdasarkan harga pasar di Jakarta ditambah 20 persen yang mencakup pajak sebesar 10 persen dan biaya administrasi sebesar 10 persen. Harga satu- an di Jakarta ini kemudian dikonversi menjadi harga pasar nasional dengan menggunakan indeks harga konstruksi yang dikembangkan Badan Pusat Statistik Tahun 2009.

\section{Realisasi Anggaran Pendidikan Dasar}

Dari realisasi anggaran pendidikan keseluruhan, baik dari pemerintah pusat maupun pemerintah provinsi dan pemerintah kabupaten/kota sebesar Rp207,41 trilyun, diperkirakan yang dialokasikan ke pendidikan dasar adalah sebesar Rp132,24 trilyun. Realisasi alokasi dana ke pendidikan dasar tersebut terdiri dari anggaran untuk SDMI sebesar Rp82,96 trilyun dan anggaran untuk SMP MTs sebesar Rp 49,28 trilyun.

Perbandingan antara realisasi anggaran pendidikan dasar tersebut dengan kebutuhan dana untuk penyelenggaraan pendidikan dasar gratis 
seperti yang diperkirakan di sub bagian 3.3 menunjukkan terjadinya kekurangan dana sebesar sekitar Rp25 trilyun, yang terdiri dari kekurangan dana untuk SDMI sebesar sekitar Rp4,5 trilyun dan kekurangan dana yang lebih besar lagi terjadi di SMP/ MTs sebesar sekitar Rp20,5 trilyun. Akibatnya, meskipun pendidikan dasar gratis sudah disosialisasikan kepada masyarakat oleh Menteri Pendidikan
Nasional dan pejabat publik lain sejak awal tahun 2009, namun dalam Kenyataannya, masih banyak terjadi pungutan bagi peserta didik, terlebih bagi peserta didik SMPMTs untuk menutup kekurangan pendanaan pendidikan dasar tersebut. Akibat lain adalah mutu sumber daya pendidikan baik pendidik dan tenaga kependidikan maupun sarana dan prasarana masih banyak yang di bawah standar.

Tabel 7. Perkiraan Biaya Total Pendidikan Dasar pada Tahun 2009

\begin{tabular}{llll}
\hline \multirow{2}{*}{ Jenis Biaya } & \multicolumn{3}{c}{ Nilai (Rp Juta) } \\
\cline { 2 - 4 } & SDMI & SMPMTs & SDMI dan SMPMTs \\
\hline A. Biaya Operasional (BO) & & & \\
$\quad$ 1. BO Pendidik \& Tenaga & & & \\
$\quad$ Kependidikan & 45.235 .562 & 26.421 .451 & 71.657 .013 \\
2. BO Bahan \& Alat Habis Pakai \& & & & \\
$\quad$ Pemeliharaan & 15.648 .630 & 8.401 .127 & 24.049 .757 \\
$\quad$ Sub Total BO & $\mathbf{6 0 . 8 8 4 . 1 9 2}$ & $\mathbf{3 4 . 8 2 2 . 5 7 8}$ & $\mathbf{9 5 . 7 0 6 . 7 7 0}$ \\
& & & \\
B. Biaya Investasi (BI) & & & \\
1. BI Pendidik \& Tenaga & & & \\
$\quad$ Kependidikan & 1.643 .384 & 930.970 & 2.574 .354 \\
2. BI Sarana dan Prasarana & 24.932 .118 & 34.008 .036 & 58.940 .154 \\
$\quad$ Sub Total BI & $\mathbf{2 6 . 5 7 5 . 5 0 1}$ & $\mathbf{3 4 . 9 3 9 . 0 0 7}$ & $\mathbf{6 1 . 5 1 4 . 5 0 8}$ \\
& & & \\
Total & $\mathbf{8 7 . 4 5 9 . 6 9 3}$ & $\mathbf{6 9 . 7 6 1 . 5 8 5}$ & $\mathbf{1 5 7 . 2 2 1 . 2 7 8}$ \\
\hline
\end{tabular}

\section{PENUTUP}

\section{Kesimpulan}

Pada bagian ini akan disampaikan kesimpulan dan saran. Kesimpulan disampaikan terlebih dahulu dan kemudian disusul dengan saran.

- Untuk menyelenggarakan pendidikan dasar dibutuhkan sumber daya pendidikan dasar. Sumber daya pendidikan dasar meliputi pendidik dan tenaga kependidikan dan sarana dan prasarana pendidikan dasar. Penyediaan pendidik dan tenaga kependidikan serta sarana dan prasarana pendidikan dasar berakibat pada biaya pendidikan dasar. Biaya pendidikan dasar dapat dikelompokkan ke dalam: a) biaya operasional pendidik dan tenaga kependidikan; b) biaya investasi pendidik dan tenaga kependidikan; c) biaya operasional bahan dan alat habis pakai serta 
pemeliharaan dan perbaikan ringan sarana dan prasarana; dan d) biaya investasi sarana dan prasarana.

- Bila keempat jenis biaya pendidikan tersebut digabung disebut biaya pendidikan. Bila biaya pendidikan ini dihitung per tahun dan dibagi dengan jumlah peserta didik disebut biaya satuan pendidikan per peserta didik per tahun. Biaya satuan pendidikan per peserta didik per tahun pada tahun 2009 adalah sebesar Rp3,691 juta untuk jenjang SDMI dan $\operatorname{Rp} 5,685$ juta untuk jenjang SMP MTs. Biaya satuan pendidikan SDMI ini terdiri dari biaya satuan operasional pendidik dan tenaga kependidikan sebesar Rp2,120 juta, biaya satuan operasional bahan dan alat habis pakai serta pemeliharaan dan perbaikan ringan sebesar Rp643 ribu, biaya satuan investasi pendidik dan tenaga kependidikan sebesar Rp23 ribu, dan biaya satuan investasi sarana dan prasarana sebesar Rp928 ribu. Sedangkan, pada jenjang SMP/ MTs biaya satuan pendidikan ini terdiri dari biaya satuan operasional pendidik dan tenaga kependidikan sebesar Rp2,947 juta, biaya satuan operasional bahan dan alat habis pakai serta pemeliharaan dan perbaikan ringan sebesar Rp792 ribu, biaya satuan investasi pendidik dan tenaga kependidikan sebesar Rp39 ribu, dan biaya satuan investasi sarana dan prasarana sebesar $\mathrm{Rp} 1,906$ juta.

- Dengan menggunakan hasil proyeksi peserta didik SDMI dan SMPMTs tahun 2009 dan hasil perkiraan biaya satuan pendidikan SDMI dan SMP/
MTs tahun 2009 serta perkiraan kebutuhan, ketersediaan, dan kekurangan sumber daya SDMTs dan SMP/ MTs dapat dihitung kebutuhan dana penyelenggaraan pendidikan dasar gratis sebesar Rp157,22 trilyun pada tahun 2009. Dari keseluruhan kebutuhan dana Rp157,22 trilyun pada tahun 2009 tersebut, disediakan untuk penyelenggaraan SDMI s e b e s a r Rp87,46trilyun dan untuk penyelenggaraan SMPAMs sebesar Rp69,762 trilyun.

- Namun, pemerintah baik pusat maupun provinsi dan kabupaten/kota hanya dapat mengalokasikan anggaran untuk pendidikan dasar secara keseluruhan sebesar Rp132,24 trilyun, yang terdiri dari anggaran untuk SD/MI sebesar Rp82,96 trilyun dan anggaran untuk SMPMTs sebesar Rp49,28 trilyun. Hal ini berarti terjadi kekurangan dana penyelenggaraan pendidikan dasar gratis sebesar sekitar Rp25 trilyun, yang terdiri dari kekurangan dana untuk SDMI sebesar sekitar Rp4,5 trilyun dan untuk SMPMTs sebesar sekitar Rp20,5 trilyun.

- Akibatnya,meskipun pendidikan dasar gratis sudah disosialisasikan kepada masyarakat oleh Menteri Pendidikan Nasional dan pejabat publik lain sejak awal tahun 2009, namun dalam kenyataannya, masih banyak terjadi pungutan bagi peserta didik, terlebih bagi peserta didik SMP MTs untuk menutup kekurangan pendanaan pendidikan dasar tersebut. Akibat lain adalah mutu sumber daya pendidikan baik pendidik dan tenaga kependidikan maupun sarana 
dan prasarana masih banyak yang di bawah standar.

\section{Saran}

- Di tahun-tahun mendatang agar amanah undang-undang tentang pendidikan dasar gratis dapat dilaksanakan secara konsisten dan bukan hanya slogan, perlu dihitung kebutuhan dana penyelenggaraan pendidikan dasar gratis dan disediakan dana yang sesuai dengan kebutuhan dana tersebut.

- Perlu dilakukan pembagian kewenangan dan kewajiban yang jelas antara pemerintah pusat, pemerintah provinsi, dan pemerintah kabupaten/kota dalam pendanaan pendidikan gratis beserta skema pendanaannya yang sesuai dengan sistem pemerintahan desentralisasi dalam $\mathrm{Ne}$ gara Kesatuan Republik Indonesia (NKRI) sehingga dapat menjamin keberlanjutan, kememadaian, dan keadilan pendanaan. Alternatif pembagian kewenangan dan kewajiban dan skema pendanaan pendidikan dasar gratis tersebut adalah sebagai berikut: 1) biaya operasional pendidik dan tenaga kependidikan didanai oleh pemerintah pusat melalui skema belanja Pemerintah Pusat terutama di Kementerian Pendidikan Nasional dan Kementerian Agama; 2) biaya operasional bahan dan alat habis pakai dan pemeliharaan didanai oleh Pemerintah Kabupaten/ Kota melalui skema Dana Alokasi Khusus (DAK); 3) biaya investasi pendidik dan tenaga kependidikan didanai oleh Pemerintah Provinsi melalui skema Dana Alokasi Khusus
(DAK); dan 4) biaya Investasi sarana dan prasarana didanai oleh Pemerintah Kabupaten/Kota melalui skema Dana Alokasi Khusus (DAK).

\section{UCAPAN TERIMA KASIH}

Penulis mengucapkan terima kasih kepada Badan Perencanaan dan Pembangunan Nasional (Bappenas) dan Bank Dunia kantor Jakarta yang mensponsori studi ini. Ucapan terima kasih juga disampaikan kepada Kementerian Pendidikan Nasional dan Kementerian Agama yang telah memberikan banyak masukan.

\section{DAFTAR PUSTAKA}

Badan Pusat Statistik. 2000. Sensus Penduduk 2000. Jakarta: BPS.

Direktorat Jenderal Peningkatan Mutu Pendidik dan Tenaga Kependidikan. 2009. Rencana Kerja Pembangunan Tahun 2009.

Direktorat Jenderal Peningkatan Mutu Pendidik dan Tenaga Kependidikan. 2009. Pagu Indikatif 2009.

Peraturan Menteri Pendidikan Nasional Nomor 22 Tahun 2006 tentang Standar Isi.

Peraturan Menteri Pendidikan Nasional Nomor 24 Tahun 2006 tentang Standar Proses. Badan Standar Nasional Pendidikan.

Peraturan Menteri Pendidikan Nasional Nomor 25 Tahun 2006 tentang Standar Pengelolaan Pendidikan. 
Peraturan Menteri Pendidikan Nasional Nomor 26 Tahun 2006 tentang Standar Pendidik dan Tenaga Kependidikan.

Peraturan Menteri Pendidikan Nasional Nomor 27 Tahun 2006 tentang Standar Sarana dan Prasarana Pendidikan.

Peraturan Pemerintah Nomor 19 Tahun 2005 tentang Standar Pendidikan Nasional.

Peraturan Pemerintah Nomor 66 Tahun 2006 tentang Daftar Gaji Pokok PNS.

Peraturan Presiden Nomor 12 Tahun 2006 tentang Tunjangan Umum bagi PNS.
Peraturan Presiden Nomor 58 Tahun 2006 tentang Tunjangan Tenaga Kependidikan.

Pusat Statistik Pendidikan. 2008. Statistik Pendidikan 2008.

UU Nomor 20 Tahun 2003 tentang Sistem Pendidikan Nasional.

UU Nomor 14 Tahun 2005 tentang Pendidik dan Dosen.

World Bank. 2006. World Bank Report 2006: Equity and Development. Washington, D.C.: the World Bank. 